原著

切除不能癌に対する徐放性 MMC カプセル留置療法の試み

徳島大学第 1 外科

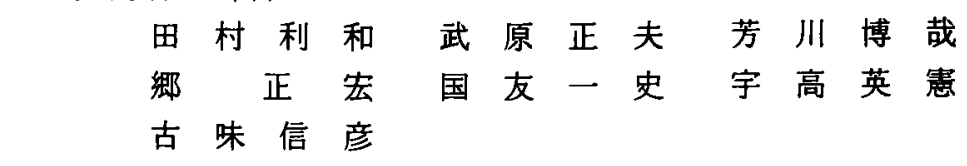

徳島大学第 1 病理

厇 瀬 隆 則

日本原子力研究所・高崎研

嘉悦勲吉田勝

\title{
A CLINICO-PATHOLOGICAL STUDY OF SLOW-RELEASING MITOMYCIN C CAPSULE IN THE TREATMENT OF INOPERABLE CANCERS
}

Toshikazu TAMURA, Masao TAKEHARA, Hirochika YOSHIKAWA, Masahiro GO, Kazufumi KUNITOMO, Hidenori UDAKA and Nobuhiko KOMI

The First Department of Surgery, School of Medicine, The University of Tokushima (Director. Prof. Nobuhiko KOMI)

Takanori HIROSE

The First Department of Pathology, School of Medicine, The University of Tokushima (Director. Prof. Kazuo HIZAWA)

Isao KAETSU and Masaru YOSHIDA

Takasaki Radiation Chemistry Reserach Establishment

切除不能癌15例に対して, 徐放性 MMC カブセル留置療法を試み, その臨床効果, 副 作用, 組織学的効果について検討を加えた。

臨床効果については，小山・斉藤班の判定基準では，15例中 PD 7 例，NC 8 例と明 らかな腫湯䑿小効果を認めなかった。発熱, 消化器症状等の全身性の副作用はなく，検 血一般，肝・腎機能検查値への影響も認められなかった。また，著しい癌性疼痛改善効 果が荤癌再発例で認められた。

組織学的には，4例で剖検あるいは試験切除にて組織学的効果を検索した，徐放性 MMC カプセルの組織学的効果は留置局所の壊死, 線維化が主体であった. MMC 針では MMC 針に隣接する部位よりむしろ少し離れた部位で組織障害が強く，その薬剤到達距 離は $\mathrm{MMC}$ 針より5〜10 mm 程度と考えられた。 また, MMC 針に隣接する部位に癌細胞 の残存を認めたが，この所見はほとんどすべての MMC 針で認めた。

切除不能癌に対する徐放性 MMC カプセル留置療法は, 東京女子医大が中心となりそ の臨床試験が全国各大学, 施設で行われており, 現時点では遠隔成績を改善させるに至っ ていないか，(1) 全身性の副作用がないこと，(2) 䐙癌での頑固な癌性疼痛を改善するこ と, (3) 組織学的には留置局所に一定範团の澏細胞壊死をおこすこと等から, 剤型, 至適 用量, 放出率の諸条件を改良することにより，有力な局所化学療法剤として従来の治療 法に比べ十分な臨床効果を期待できると考えられる。

事引用語：徐放性 MMC カプセル，切除不能癌 


\section{I. 緒 百}

徐放性マイトマイシンCカブセル（以下 MMCカプ セル）は低温過冷却状態における放射線重合を利用し， 高分子担体中に MMCを含有させ徐放性を賦与した

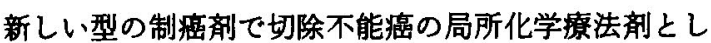
て注目されている゙．今回，著者らは切除不能癌15例に 対してMMCカプセルの留置療法を試み, 臨床効果, 副作用, 組織学的効果等について検討を加党若干の知 見を得たので報告する。

\section{II. 対象およU゚方法}

\section{1. 対象}

今回, MMC カブセル留置療法の対象となったのは, 治撚切除不能癌あるいは再発癌の15例で，その内訳は 胆衰癌 3 例，胆管癌 2 例，䐙癌 2 例，食道癌 1 例，胃 癌 2 例, 直腸癌 3 例, 頭䅡部癌 1 例，甲状腺癌 1 例で あった（表 1 )。

\section{2. 方法}

MMC カブセルの 2 種類の剂型であるボタン型（以

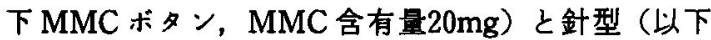
$\mathrm{MMC}$ 針，同5mg）（図 1）を原発部位，転移部位ある いは腫掦遭戏部の腫瘍内およびその周辺に MMC 総 量で15 100mg（平均 $46.7 \mathrm{mg}$ ) 留置し, 術後腫湯径測

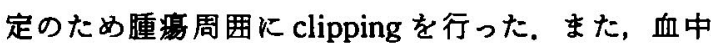
MMC 濃度の測定は，E. coli B 株を被検菌とする薄層 カッブ法により，測定限界は $0.0063 \mu \mathrm{g} / \mathrm{ml}$ でそれ以下 は trace とした。なお，MMC 針を用いた胆衰癌 2 例，

苏癌 1 例，甲状腺癌 1 例については，剖検あるいは試 験切除にて組織学的効果を検索した。

III. 成

\section{1. 臨床効果}

全身的な化学療法，免疫療法，放射線療法を併用乙

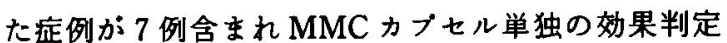
は困難であるが，剖榆あるいはレ線的に clip 径にて盾 瘍径を計測し効果判定の基準にした，厚生省小山，斉 藤班の判定基準による評価では，15例中 PD 7 例， NC 8 例と明らかな腫效果を認めなかった（表 1 ). しか し, 症例12の膵癌再発例は，MMC ボタン留置後417日 の生存を得られ，著しい疼痛改善効果を認めた。

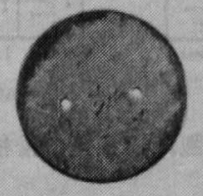

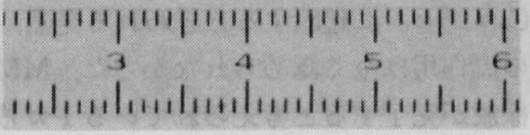

图 1 MMC カプセル

右：MMC 針 (5mg). 左：MMC ボタン (20mg)

表 1 徐放性 MMC カブセル留娄症例

\begin{tabular}{|c|c|c|c|c|c|c|c|c|c|c|}
\hline 应例 & 年 $_{\text {珄 }}^{\text {令 }}$ & 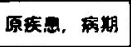 & 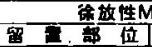 & 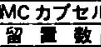 & A $(n y)$ & 阱用 弶法 & 生㞭期的 & 剅作用 & 効 果 & 用手 勅 \\
\hline 1 & $73 \mathrm{~F}$ & 胆管患 IV & 肝右蓝下面 & 10 & 50 & し & 30 & なし & PD & 让 的 \\
\hline 2 & $74 \mathrm{~F}$ & E IV & 肝右暻，胆要 & it & 25 & な & 23 & なし & PD & 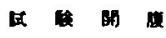 \\
\hline 3 & $82 \mathrm{M}$ & 面部舟 IV & 暲可部 & 10 & 50 & な & 66 & な し & PD & 㫜空空吻合 \\
\hline 4 & $65 \mathrm{M}$ & 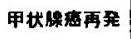 & 皮田枟部 & at & 15 & L & 45 & な & PD & L \\
\hline 5 & $27 \mathrm{~F}$ & 月畐再無 & 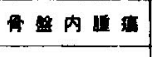 & 10 & 50 & 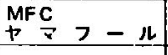 & 197 & なし & NC & 式 的 筷 \\
\hline 6 & $61 \mathrm{~F}$ & - 囿 IV & 肝 右 素 & if & 25 & L & 49 & なし & PD & 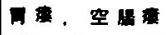 \\
\hline 7 & 5) $F$ & 㫜 $1 \mathrm{tV}$ & $\mathbf{E}$ & 12 & 60 & む し & 92 & な し & NC & 㳦地 \\
\hline 8 & $70 \mathrm{~F}$ & 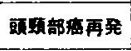 & 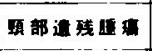 & it & 25 & $\begin{array}{l}\text { ベブレオマイシン } \\
\text { MMC }\end{array}$ & 171 & な & PD & 10 切 賖 \\
\hline 9 & $60 F$ & 直明垔再 & 量内粗 & it & 25 & $\begin{array}{l}O K-432 \\
\rightarrow \nabla>-\mu\end{array}$ & $\begin{array}{c}282 \\
\text { (生存中) }\end{array}$ & な & NC & 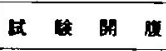 \\
\hline 10 & $55 F$ & Is $\mathrm{IV}$ & 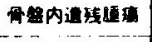 & it & 25 & な & 132 & な & NC & 直切断术 \\
\hline 11 & $71 F$ & 百的里再罢 & 盘内 内古 & ホホタン 4 & 80 & $5-F u$ & & な $し$ & PD & ハルトマン手整 \\
\hline 12 & $52 \mathrm{~F}$ & 18 要再产 & SMA 根部监夏 & ボン 3 & 60 & $\begin{array}{l}\text { Minc, } 5 F_{4} \\
\text { Limec } 5,000 \text { reds }\end{array}$ & 417 & な し & NC & 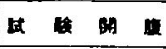 \\
\hline 13 & $57 \mathrm{~F}$ & 㫜 $\mathrm{N}$ & 肝右㫫下面 & ボタン 5 & 100 & †マフ-ル & & t & NC & 证 \\
\hline 14 & $54 \mathrm{~F}$ & 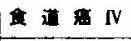 & 心外的漫部 & ボタン 2 & 40 & ヤマフール & 427 & な し & NC & 是 切賖 \\
\hline 15 & $50 \mathrm{~F}$ & 㔭管 盘 IV & 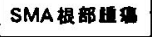 & ボタン 2 & 40 & な & & な & NC & 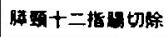 \\
\hline
\end{tabular}



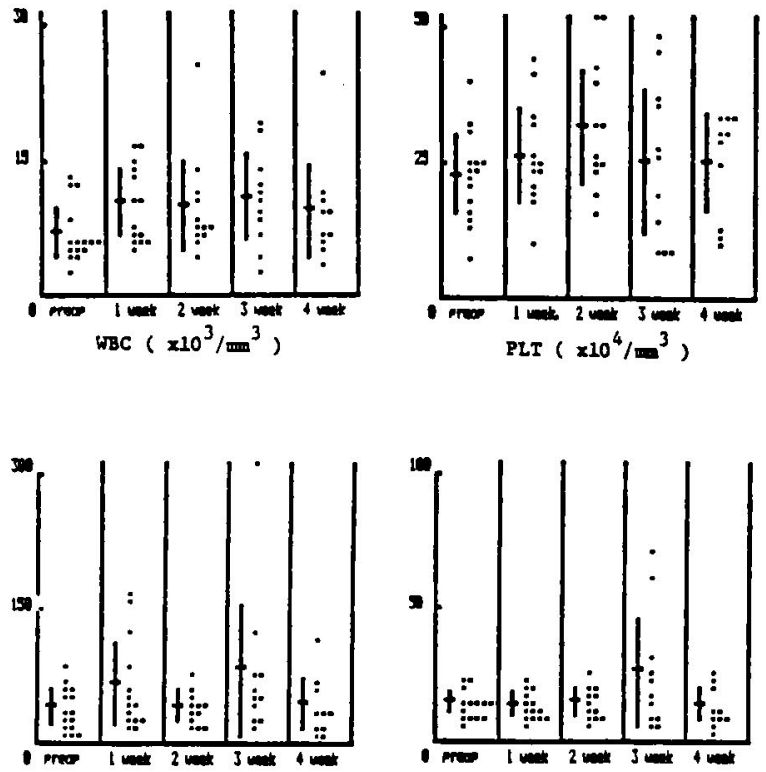

$\cot (\mathrm{IV} / \mathrm{L})$

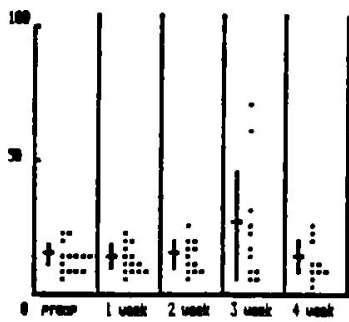

BUN ( mg/d1)

図 2 烸床検查值の推移

\section{2. 副作用}

MMC カプセルに起因すると思われる発熱, 消化器 症状等の副作用は全く認められなかった，MMCカプ セルの徐放が完了すると考えられている1力月後まで の臨床検查値の推移を検討したが，白血球，血小板は むしろ増加する傾向にあった，症例 1 では 4 週間後に 著明な白血球减少 $\left(1,000 / \mathrm{mm}^{3}\right)$ ，血小板减少 $(32,000 /$ $\mathrm{mm}^{3}$ ) および出血傾向を認めたが，これらは末期の DIC によるものと思われた．肝機能検查ではGOT の 一過性上昇を症例 1，3，15で認めたがますなく回復 した。腎機能検查ではBUN の上昇を症例 $1 ， 2$ で認め たか， 2 例とも未期の腎不全によるものと思われた(图 2 ).

\section{3. 血中 $M M C$ 湌度}

血中 $\mathrm{MMC}$ 濃度は症例 $1 ， 5 ， 7 ， 12$ の 4 例で測定 したか，症例 5 (MMC 針50mg) で 3 週間後に0.021 $\mu \mathrm{g} / \mathrm{ml}$, 症例 7 (MMC 倽60mg) で 3 日後に0.007 $\mu \mathrm{g}$ / $\mathrm{ml}$ の值を示したが，それ以外はすべて trace であっ た.

\section{4. 組織学的効果}

MMC 針を用いた症例 1 4 Kついては剖恰あるい は試験切除により組織学的効果を検索する機会を得 た.

（1）症例 1 ：胆管癌，73歳，女性.

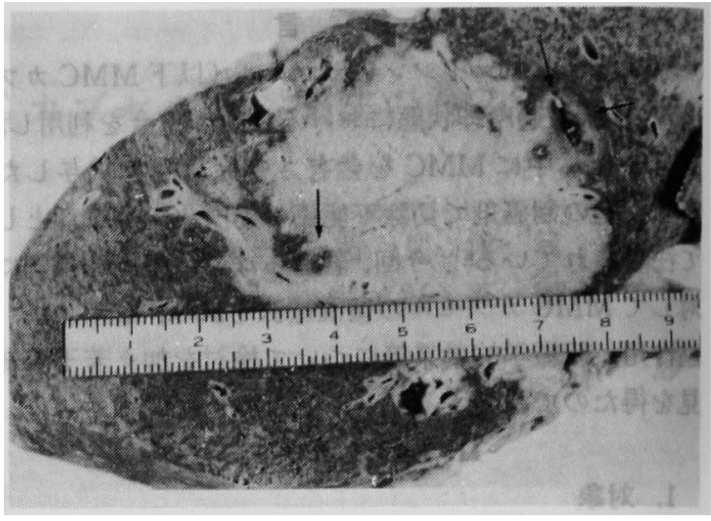

目 3 剖検栖本肉眼所見

腫啺周辺き数本の MMC 針が認められる（矢印： MMC 針)

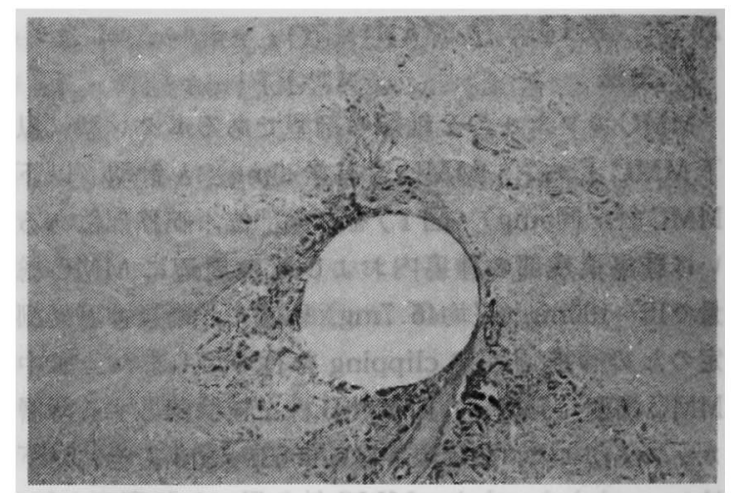

图 4 MMC 針周囲はびん性の垻死を示す(PAS $\times$ 20)

肝門部を経て肝内に発育した腫福辺縁部に数本の $\mathrm{MMC}$ 針が認められ，肉眼的には $\mathrm{MMC}$ 針周囲直径約 5〜10mm の部分はほぼ同心円状に灰白色を呈し境死 を思わせた（図 3)，組織学的には，MMC 針周团は細 胞構造が汪とんど破填され好中球を主体とする炎症性

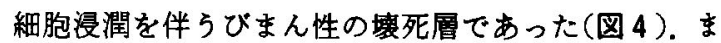
た，その外側には結合織性の被膜を介して細胞密度の そしい線維化を示す部分が認められ（図 5)，肝では MMC 針がかなり広汎な領域に影䈏を及ぼすことが考 えられた.しかし，MMC 針に隣接した部位では変性は 認められるが，核が明瞭な癌細胞を認めた(図 6)。 た，他のすべての MMC 針に隣接した部位に同様に癌 細胞の残存を認めた。

（2）症例 $2 ：$ 胆慗癌, 74藏, 女性.

胆衰の $\mathrm{MMC}$ 針周囲は肉眼的に直径約 $10 \mathrm{~mm}$ の部 


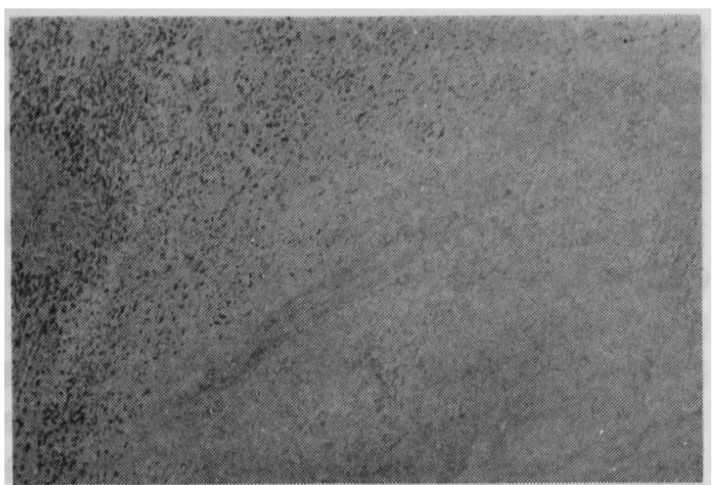

图 5 境死届の外側に䟩合筒性の被膜を介して線維化 居を認める（HE $\times 50 ）$

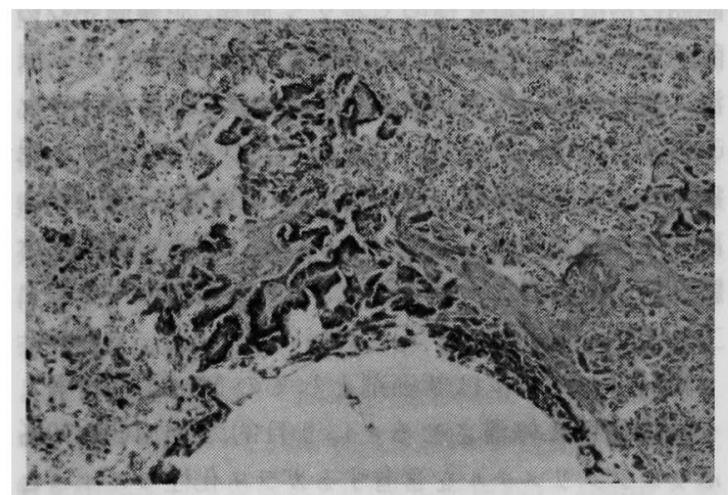

图 $6 \mathrm{MMC}$ 飫に隆接した部位に viableな粮細胞の 残存を認める（PAS $\times 50 ）$

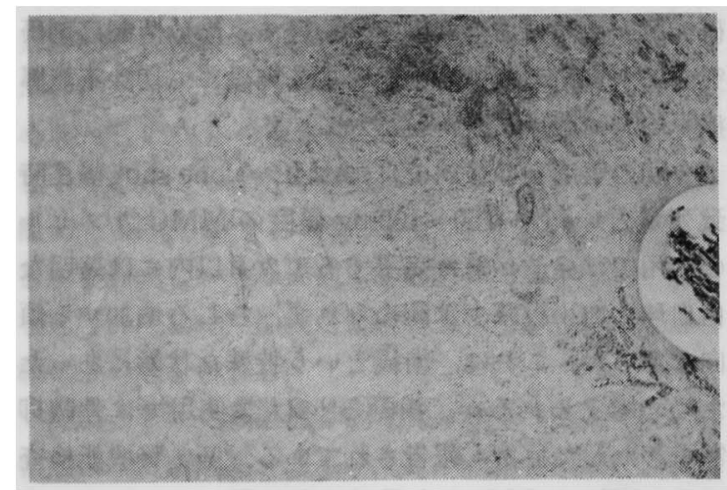

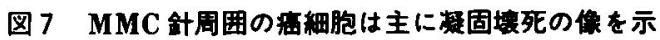
† $(\mathrm{HE} \times 20)$

分が灰白色を呈していた。組織学的には, MMC 針周囲 の癌細胞は主に凝固壊死の像を示した（図７）。壊死は MMC 針より少し離れた部位でさしろ強く，MMC 針

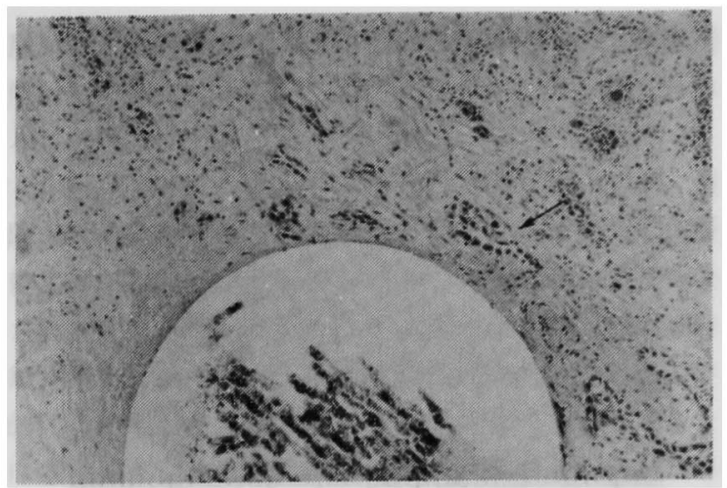

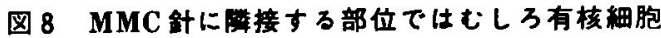
（矢印）が多い（HE ×50）

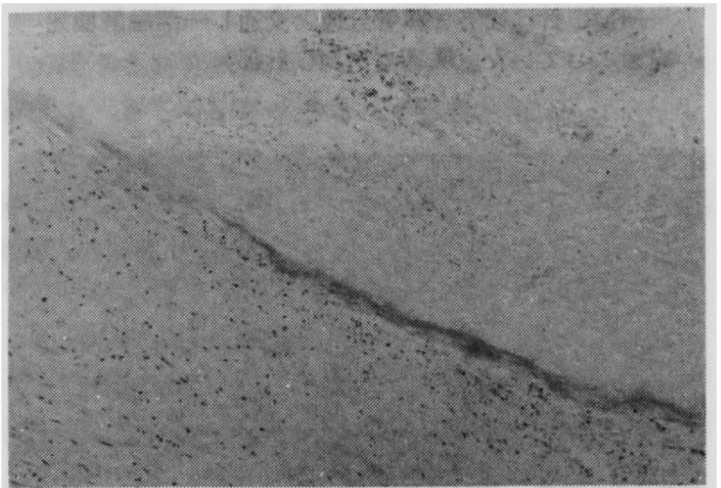

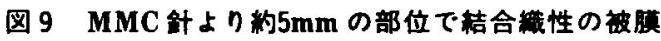
を認める（HE ×50）

に隣接する部位では有核細胞が多い（図 8).また， $\mathrm{MMC}$ 針より約 $5 \mathrm{~mm}$ の部位で結合織性の被膜を形成 し,その周辺に組織球系の細胞の遊出が認められた(図 9).

（3）症例 3：脇頭部癌，82歳，男性.

苹頭部の MMC 針は膘管分枝之交通し，その部位で 一部㑊組織の融解壊死を起こしていた（図10)。組織学 的には MMC針周囲は壇死および線維化が主体で あったが，荤小葉の萎綰性変化が認められた（図11).

（4）症例 4 ：甲状腺末分化癌，65歳，女性.

皮佰移部位に留置した MMC 針周囲直径約5７ $\mathrm{mm}$ の部分は厕白色を呈し壊死を思わせた(図12)。組 織学的には, $\mathrm{MMC}$ 針周囲はびまん性の壊死を示した が，その程度は軽く、MMC 針周曲にも末分化癌の残存 を認めた（図13）.

$$
\text { IV. 考 察 }
$$

癌に対する集学的治㞠法が発達した今日でる切除不 


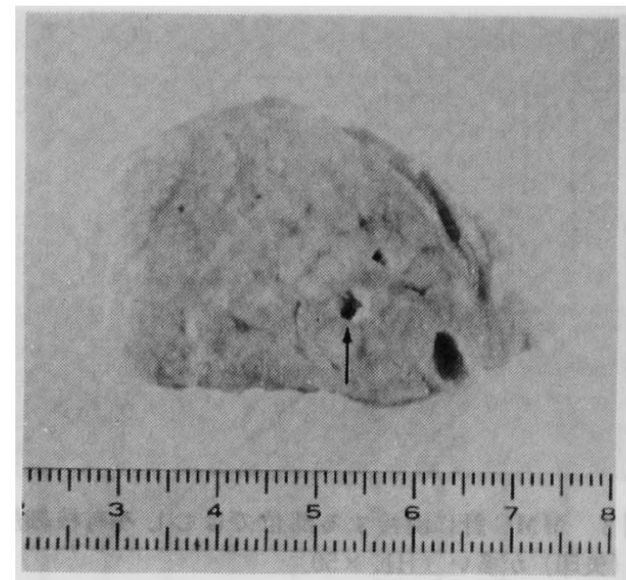

図10 剖検祭本肉眼所見（症例 2）

$\mathrm{MMC}$ 針は後方で勝管分枝と交通し一部融解壊死 をおこしていた（矢印：MMC 針部）

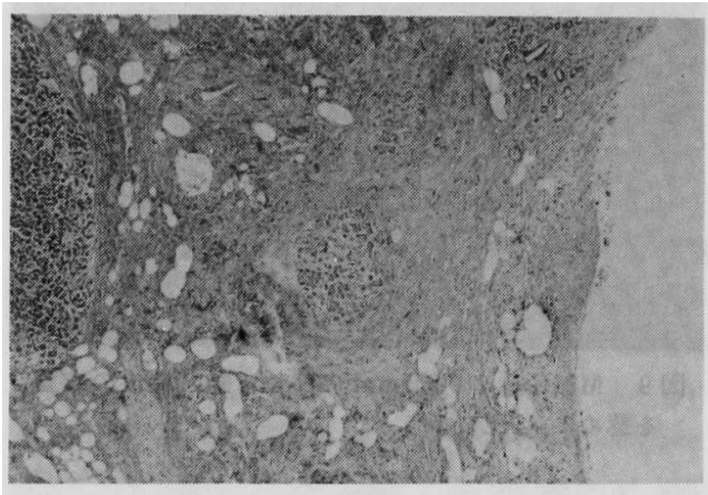

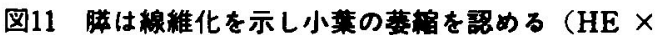
$50)$

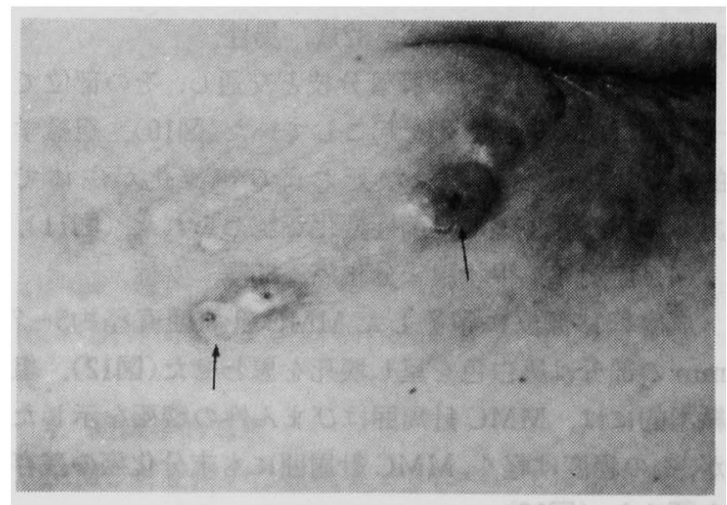

图12甲状腺演皮成転移（症例 4 ）

MMC 針周囲は厕白色を呈している（知印： MMC 針)

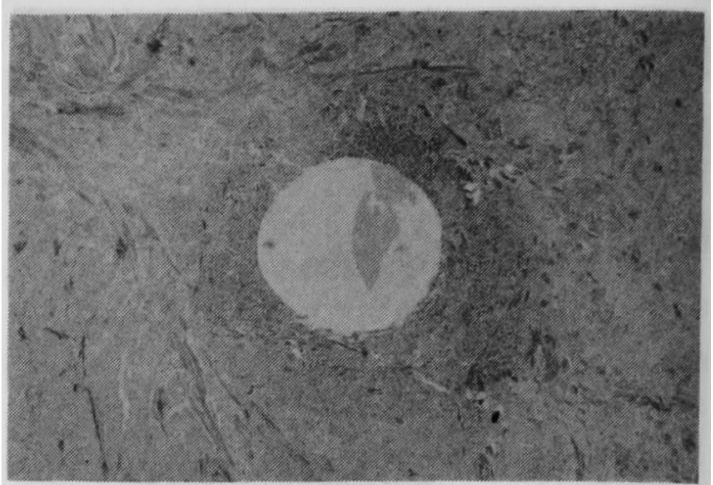

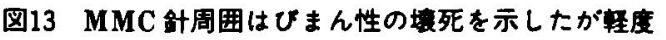
である（HE $\times 20 ）$

能癌の治療は困難を極めており 除不能癌には, 全身的な化学療法, 動注療法, 免疫療 法, 放射線療法, 温熱療法等が行われているが予後を 改善するに至っていないまた，このような切除不能 癌では全身状態が悪い例が多く, 大量の制癌剂使用は, 副作用の点で問題が多く，こうした状況下で制癌剤を 隀境局所に効率よく停沮させ, 全身的な副作用を防ぐ 工夫が試みられている。

MMC カプセルは制癌偊としての MMCを効率よ く腫富局所に停滞させるとい5目的で MMCを10\% ボリメタクリメチルを含有するガラス化性モノマーと 混合し相互分散させ, $-80^{\circ} \mathrm{C}$ 凍結下に ${ }^{60} \mathrm{Co}$ ¿ $1 \times 10^{6}$ rads 照射し徐放性を賦与した複合組成物である31).現 在, MMC カプセルは, 東京女子医大および日本原子力 研究所 - 高崎研での基礎実験を経て, 徐放性制癌剂研 究会に所属する全国各大学および施設にて切除不能䐙 癌を中心に臨床試験が行われている。

今回の著者らの検討では, MMCの one shot 静注時 致死量といわれる50 100mg 程度の $\mathrm{MMC}$ ガ゙ル の使用では徐放がほぼ完了する 1 カ月以内には著明な 白血球・血小板减少は認められず，むしろ増加する㑯 向にあった。これは，術後といら特殊な状態にあった ためと考えられるが，线野ららの大量使用では骨䯣抑 制をきたした症例も報告されている，肝・腎機能検査 では一過性の GOT の上昇が 3 例に認められたが，3

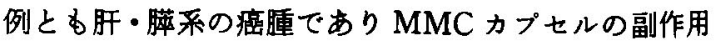

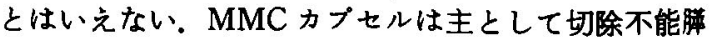
癌の頑固な癌性疼痛の改善に効果があることが諸

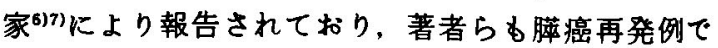
$\mathrm{MMC}$ ボタン $60 \mathrm{mg}$ を使用し頑固な癌性疼痛が消失 し，それが 1 年以上持続した症例を経験した。また， 
浅野ら5は ク，著者らが指摘した $\mathrm{MMC}$ 針による膵管分枝部の損 伤と考文合わせて今後の問題となろう。

予後については，著者らの15例でははっきりした改

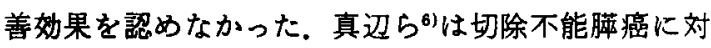
して MMCカプセル $80 \mathrm{mg}$ 以下の使用量では平均 5.9 カ月と予後を改善するに至っていない，羽生ら゙も切 除不能苹癌41例に MMCボタンを使用した結果, 遠隔 成綪の向上を認めていないが，1 年以上の生存例を 6

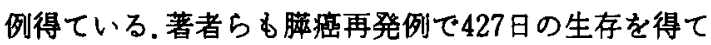
いるが，腫禓効果については剖検が行われていないの で確認できなかった。

MMC カプセルの組織学的効果については，すでに $\mathrm{MMC}$ ボタンについては中村 $5^{1)}$ ，真辺 $5^{6)}, \mathrm{MMC}$ 針 については著者らのの報告がある. 今回, 著者らは 4 例 のMMC 針使用例で組織学的効果を検索する機会を 得た. $\mathrm{MMC}$ 針からの MMCの徐放はあくまで単純払 散であり，それによる組織障害は MMCによる組織壊 死, 線維化が主体である.MMC 針からの薬剂致達距離 は荗器、癌腫の種類により差があると考えられるが， 著者らの 4 例では肝, 胆衰, 胲, 皮闲の順であったが， これらは剖検あるいは試験切除の時期でる異なるとも 考えられた。しかし，MMC 針の薬剤到達距離は MMC 針を中心にしてはぼ同心円状に半径約5－10 mm と考 えるのが妥当であろう。また，以前，著者らが指摘し た MMC 針に隣接する部位の癌細胞の残存は，検索し 得たすべての MMC 針で認められた。しかむ，MMC 針周囲の癌細胞の残存が全周性に一様でなくばらつき が存在した。これは, MMC 針の小孔の存在, 重力のた め MMC 針からの徐放が一様でなく薬郕浱度差が存 在することから解釈可能である。 また，胆管癌，胆衰 癌例で MMC 針から約5７mmの部位で結合樴性の 被膜を形成し，その周辺に組織球系の貪食細胞の遊出 を認めた所見は，徐放がほほ完了した後の組織の修復 機転とも考えられる。

MMC ボタンの組織学的効果については浅野ら5は 留意部位に癌壇死を認めず，ボタン内の $\mathrm{MMC}$ 残量む 多いことから MMCボタンより MMC 針の有効性を 指摘している。著者らは, MMC ボタン例の剖検例を経 験していないか，成犬を用いた実験では，MMCボタン は留置局所に葴器との間に組織壊死によると思われる 薄い偽膜を形成し，薬剤の漫透が障害され，組維障害 は減弱するので，むしろ MMC 針を直接組織内に留置

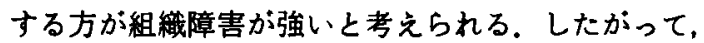

MMC カブセルの使用方法として MMC 針を畽渲局 所に1.0 2.0cm 間隔で留置するのがよいと考えられ る.

今後, MMC カプセルが疼痛改善奻果のみでなく,遠 隔成績の向上に奇与するためには，組織障害性，大量 使用時の重症苹炎，骨髄抑制等の副作用の問題が解決 されなければならない，しかし，全身的には one shot 静注時致死量程度の使用量では副作用はなく, 組織学 的には留置局所に一定範田の癌細胞壊死をおこすこと は事実であり，郕型，賦形材質，至適用量，放出率等 の諸条件を検討すれば切除不能癌の局所化学療法剂と して従来の治療法に比べ十分な臨床奻果を期待できる と考えられた。

\section{V. 結 語}

切除不能癌15例に対してMMCカプセル留置療法 を試み，若干の知見を得たので報告した。

なお，本論文の要旨は第 2 回 (1982年 2 月，高崎)，第 4 回 (1983年 2 月, 名古屋) 徐放性制癌剤研究会, 第58回中国 四国外科学会（1983年11月，米子）にて哭表した。

$$
\text { 文献 }
$$

1）中村光司，高田忠敬，高崎 健ほか：切除不能胼痕 に対する徐放性 MMC カブセルの使用経駼，癌と 化学療法, 7:1824-1831，1980.

2）木南義男，新村康二，滝田佳夫はか：切除暗応外胼

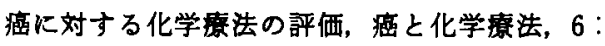
1267-1272, 1979.

3）嘉说 勲, 吉田・勝, 山田明夫ほか：埋め込及化学 療法用制がん率一高分子䄍合体の形状・構造の機 能の関㐿, 人工渡器, $9: 1128-1131,1980$.

4）嘉㙂 项, 吉田 勝, 线野雅春ほか：徐故性制癌剂 カブセルの開発とその適用，人工䁍器，11： 217-220, 1982.

5）浅野栄一,神野正博, 沢 敏治法か：進行型愺癌に 対する徐放性制癌绪大量投与の経鍳，外科診療， $25: 1203-1208,1983$.

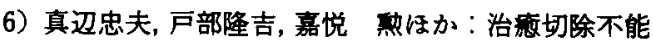
胼癌に対する徐放性制癌剤の使用経臨，臨外，37： $1397-1403,1982$.

7）羽生富士夫, 中村光司：MMC 徐放性カブセルに 上了切除不能膦癌の治療, Medicina，4： $582-583,1983$.

8）田村利和, 郷 正宏, 和田大助ほか：切除不能消化 器癌に対する徐放性 MMC カブセルの使用経匼 一剖满例における病理組織学的变化を中心にして 一, 癌と化学療法, $10: 41-45,1983$. 